\title{
HUBUNGAN ANTARA LAMA PEMBERIAN ASI DENGAN STATUS GIZI BALITA (PB/U) USIA 24 - 59 BULAN DI PUSKESMAS SIDOREJO KIDUL KOTA SALATIGA TAHUN 2018
}

\author{
CORRELATION BETWEEN THE DURATION OF BREASFEEDING WITH \\ NUTRITIONAL STATUS (PB/U) TODDLER AGE 24 - 59 MONTH AT \\ PUSKESMAS SIDOREJO KIDUL SALATIGA CITY YEAR 2018
}

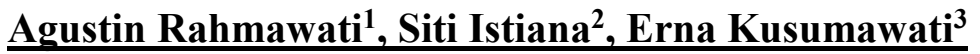

${ }^{1}$ Program Studi DIII Kebidanan, Fakultas Ilmu Keperawatan dan Kesehatan, Universitas Muhammadiyah Semarang

Email : agustinrahmawati@unimus.ac.id

\begin{abstract}
ABSTRAK
Upaya peningkatan status gizi masyarakat termasuk penurunan prevalensi balita pendek menjadi salah satu prioritas pembangunan nasional yang tercantum di dalam sasaran pokok Rencana Pembangunan jangka Menengah Tahun 2015 - 2019. Tujuan penelitian ini adalah untuk menganalisis lama pemberian ASI dengan status gizi balita berdasar PB/U. Penelitian ini melibatkan 40 Balita usia 24 - 59 Bulan di Puskesmas Sidorejo Kidul Kota Salatiga. Analisis chi square untuk melihat adakah hubungan diantara kedua variabel tersebut. Hasil penelitian menunjukkan Lama pemberian ASI mayoritas $\geq 2$ th sebanyak 72,5\%, Status gizi balita usia 24-59 bulan mayoritas berstatus gizi normal berdasar PB/U sebanyak 62,5\%, Ada hubungan antara lama pemberian ASI dengan status gizi balita p value 0,014.
\end{abstract}

Kata kunci: balita, status gizi, ASI

\section{ABSTRACT}

Efforts to improve the nutritional status of the community, including the reduction in the prevalence of short-term toddlers, are one of the national development priorities listed in the main targets for the Medium-Term Development Plan for 2015-2019. The purpose of this study was to analyze the duration of breastfeeding with nutritional status of children under PB / U. This study involved 40 toddlers aged 24 - 59 months at the Sidorejo Kidul Health Center in Salatiga City. Chi square analysis to see is there a correlation between the two variables. The results showed that the majority of duration breasfeeding were $\geq 2$ th as much as $72.5 \%$. The nutritional status of children aged 24-59 months was mostly normal nutritional status based on PB / U as much as $62.5 \%$. There is a correlation between the duration of breastfeeding and the nutritional status of the toddler $p$ value 0.014 .

Keywords: toddler, nutrition status, breasfeeding

\section{PENDAHULUAN}

Program kesehatan Ibu dan Anak merupakan salah satu prioritas Kementerian Kesehatan dan keberhasilan program KIA menjadi salah satu indikator utama dalam Rencana Pembangunan Jangka
Panjang Nasional (RPJPN) 2005 2025. Pada program SDGs sendiri tercantum salah satu tujuan yaitu Menjamin kehidupan yang sehat serta mendorong kesejahteraan bagi semua orang di segala usia, hal ini 
juga termasuk pada masa kehamilan, persalinan, nifas, dan reproduksi.

Kondisi kesehatan

masyarakat Indonesia saat ini sedang terpuruk. Hal ini ditandai dengan ditemukannya kasus-kasus gizi buruk di beberapa daerah di Indonesia. Data Statistik Kesehatan Departemen Kesehatan RI menyebutkan bahwa pada tahun 2005 dari 941.973.879 penduduk Indonesia, 6\% atau sekitar 14,5 juta orang menderita gizi buruk. Penderita gizi buruk umumnya anakanak di bawah usia 5 tahun (Balita). Status gizi Balita merupakan salah satu indikator yang menggambarkan tingkat kesejahteraan masyarakat. Salah satu cara penilaian status gizi Balita yaitu dengan pengukuran secara antopometrik Panjang Berat Badan menurut Umur (PB/U). (BKKBN, 2010).

ASI merupakan makanan yang paling sempurna, kandungan gizi sesuai dengan kebutuhan, pertumbuhan dan perkembangan anak yang optimal. Manfaat menyusui tidak hanya dapat menjalin kasih sayang, tetapi dapat mengurangi perdarahan setelah melahirkan, mempercepat pemulihan kesehatan ibu, menunda kehamilan, mengurangi resiko terkena kanker payudara, dan merupakan kebahagiaan tersendiri bagi ibu (Lucy, 2006: 25).

Tumbuh kembang anak dapat optimal, Wold Health Organization (WHO) menetapkan Global Strategy For Infant at Young Child Feeding yang berada di Indonesia ditindaklanjuti dengan Penyusunan Strategi Nasional Pemberian Makanan pada Bayi dan Anak. Strategi tersebut mencakup pemberian ASI dalam 30 menit setelah kelahiran, memberikan ASI saja atau ASI Eksklusif sejak lahir sampai bayi berumur 6 bulan, memberikan makanan pendamping ASI (MP/ASI) yang cukup dan bermutu sejak bayi umur 6 bulan dan meneruskan pemberian ASI sampai anak berumur 2 tahun (DepKes RI, 2006).

Pembangunan kesehatan dalam periode tahun 2015-2019 difokuskan pada empat program prioritas yaitu penurunan angka kematian ibu dan bayi, penurunan prevalensi balita pendek (stunting), pengendalian penyakit menular dan pengendalian penyakit tidak menular. Upaya peningkatan status gizi masyarakat termasuk penurunan prevalensi balita pendek menjadi salah satu prioritas pembangunan nasional yang tercantum di dalam sasaran pokok Rencana Pembangunan jangka Menengah Tahun 2015 - 2019. Target penurunan prevalensi stunting (pendek dan sangat pendek) pada anak baduta (dibawah 2 tahun) adalah menjadi 28\% (RPJMN, 2015 - 2019).

Studi pendahuluan dilakukan di wilayah Puskesmas Sidorejo Kidul pada bulan Agustus 2018, dengan cara wawancara langsung kepada ibu yang memiliki anak usia 24-59 bulan diperoleh data bahwa dari 10 Balita, terdapat 2 anak pendek (20\%) dengan usia pemberian ASI kurang dari 2 tahun.

Dari data diatas, penulis tertarik untuk melakukan penelitian Hubungan Lama Pemberian ASI dengan Status Gizi Anak Usia 24-59 Bulan di Puskesmas Sidorejo Kidul Tahun 2018. 


\section{METODE PENELITIAN}

Jenis penelitian ini adalah penelitian survei analitik dengan menggunakan pendekatan waktu secara crossectional.

Subyek penelitian adalah ibuibu yang mempunyai balita umur 2459 bulan, yang datang menimbangkan balitanya ke Posyandu di wilayah Puskesmas Sidorejo Kidul Kota Salatiga Tahun 2018 yang berjumlah 40 responden dengan teknik pengambilan sampel systematic random. Alat yang digunakan dalam penelitian ini menggunakan wawancara langsung kepada responden. Variabel dalam penelitian ini menggunakan variabel bebas yaitu lama pemberian ASI dan variabel terikat yaitu status gizi anak usia 24-59 bulan berdasar $\mathrm{PB} / \mathrm{U}$, yang diukur dengan mengunakan skala ordinal. Analisa data menggunakan Chi Square.

\section{HASIL DAN PEMBAHASAN \\ Hasil}

\section{Usia}

Tabel 1 menunjukkan karakteristik umur balita yang dilibatkan dalam penelitian ini. Dari 40 balita diperoleh rata-rata usia balita 38 bulan. Usia terendah balita 27 bulan dan usia tertinggi 57 bulan. Usia tersering dalam penelitian ini adalah 30 bulan.

Tabel 1. Distribusi Usia Balita 24-59 Bulan

\begin{tabular}{clc}
\hline No & \multicolumn{1}{c}{ Usia } & Jumlah \\
\hline 1 & Mean & 38,53 \\
\hline 2 & Median & 36,50 \\
\hline 3 & Mode & 30 \\
\hline 4 & Minimum & 27 \\
\hline 5 & Maximum & 57 \\
\hline
\end{tabular}

\section{Lama Pemberian ASI}

Tabel 2. Distribusi Frekuensi

Karakteristik Responden

Berdasarkan Lama Pemberian

ASI

\begin{tabular}{cccc}
\hline No & Usia & Jumlah & $\mathbf{\%}$ \\
\hline 1 & $<2$ th & 11 & $27,5 \%$ \\
\hline 2 & $\geq 2$ th & 29 & $72,5 \%$ \\
\hline & Total & 40 & $100 \%$ \\
\hline
\end{tabular}

Dari tabel diatas dapat diketahui frekuensi terbanyak dimiliki oleh anak yang mempunyai lama pemberian ASI $\geq 2$ tahun $(72,5 \%)$.

Penelitian ini terdapat ibu yang tidak memberikan ASI selama 2 tahun karena pada ibu yang sibuk dengan pekerjaanya cenderung tidak mempunyai waktu untuk memberikan ASI penuh sampai anak usia 2 tahun. Ibu yang mempunyai kesibukan dengan pekerjaannya lebih memilih memberikan susu formula yang dianggap lebih praktis, sehingga menyebabkan pemberian ASI pada anak tidak sampai usia 2 tahun. Seringkali anak tidak mau menyusu dengan sendirinya, bayi bingung puting susu dan bayi memilih minum susu formula yang dikarenakan seorang ibu yang tidak mau memberikan ASI terutama pada ASI Eksklusif. Hal ini sesuai menurut (DepKes.RI, 2006) pembentukan status gizi anak yang baik dipengaruhi oleh pola pemberian ASI Eksklusif sampai anak usia 6 bulan kemudian dilanjutkan sampai anak berusia 2 tahun.

Kendala yang lain yaitu keadaan ibu dan bayi. Pemberian ASI akan terhambat jika terdapat kelainan misalnya pada ibu seperti 
putting ibu lecet, puting ibu luka, payudara bengkak, engorgement, mastitis, dan abses payudara. Sedangkan pada bayi misalnya bayi sakit atau abnormalitas bayi. Selain itu, kekhawatiran ibu apabila ASI-nya tidak mencukupi kebutuhan bayinya. Ibu sering kali merasa cemas dan khawatir bila bayinya masih terus saja menangis walaupun sudah diberikan ASI. Para ibu dan anggota keluarga seringkali beranggapan hal tersebut disebabkan karena bayi tersebut masih lapar sehingga diberikan makanan atau minuman lain.

\section{Status Gizi Balita}

Tabel 3. Distribusi Frekuensi Karakteristik Responden Berdasarkan Status Gizi Balita

\begin{tabular}{cccc}
\hline No & Usia & Jumlah & \% \\
\hline 1 & Normal & 25 & $62,5 \%$ \\
\hline 2 & Pendek & 15 & $37,5 \%$ \\
\hline & Total & 40 & $100 \%$ \\
\hline
\end{tabular}

Berdasarkan tabel diatas mayoritas anak memiliki status gizi normal berdasar $\mathrm{PB} / \mathrm{U}$ yaitu 25 balita $(62,5 \%)$ dan sebanyak 15 balita $(37,5 \%)$.

Keadaan status gizi anak dipengaruhi oleh beberapa faktor, baik secara langsung maupun tidak langsung. Faktor secara langsung diantaranya asupan makan dan penyakit, sedangkan untuk faktor secara tidak langsung dipengaruhi oleh status ekonomi, tingkat pendidikan ibu, jumlah anak dalam keluarga dan usia penghentian lama pemberian ASI (Moerly, 2006: 35). Salah satu cara penilaian status gizi anak dalam penelitian ini yaitu menggunakan pengukuran secara
anthropometrik menggunakan indeks Panjang Badan (PB) menurut Umur (PB/U).

\section{Hubungan Lama Pemberian ASI dengan Status Gizi Balita}

Tabel 4. Distribusi Frekuensi

Lama Pemberian ASI dengan

Status Gizi Balita di Puskesmas

Sidorejo Kidul Kota Salatiga

\begin{tabular}{|c|c|c|c|c|c|}
\hline \multirow{3}{*}{$\begin{array}{l}\text { Lama } \\
\text { Pemberian } \\
\text { ASI }\end{array}$} & \multicolumn{4}{|c|}{ Status Gizi } & \multirow[t]{3}{*}{ Total } \\
\hline & \multicolumn{2}{|c|}{ Normal } & \multicolumn{2}{|c|}{ Pendek } & \\
\hline & $n$ & $\%$ & n & $\%$ & \\
\hline$<2$ th & 3 & $30 \%$ & 7 & $70 \%$ & $100 \%$ \\
\hline$\geq 2$ th & 22 & $73,3 \%$ & 8 & $26,7 \%$ & $100 \%$ \\
\hline \multicolumn{6}{|l|}{$\mathrm{X}^{2}=0,014$} \\
\hline & Ber & asark & & tabel & 4 \\
\hline
\end{tabular}

pemberian ASI dari seluruh kategori pada anak $\geq 2$ th dengan status gizi $\mathrm{PB} / \mathrm{U}$ normal sebanyak 22 balita $(73,3 \%)$. Sedangkan pada lama pemberian ASI pada anak $<2$ th didapatkan status gizi balita berdasar $\mathrm{PB} / \mathrm{U}$ pada kategori pendek sebanyak 7 balita (70\%). Hasil analisa chi square didapatkan hasil $p$ value 0,014 artinya terdapat hubungan antara lama pemberian ASI dengan status gizi balita berdasar $\mathrm{PB} / \mathrm{U}$.

ASI merupakan sumber zat gizi berkualitas tinggi karena dapat mengurangi terjadinya penyakit dan kematian akibat diare serta infeksi saluran pernafasan (Kodyat, 2005 :123). Pemberian ASI dihentikan pada anak usia 2 tahun, karena zat-zat terkandung di dalam ASI sudah tidak memenuhi kebutuhan, sehingga ASI sudah harus sudah digantikan dengan makanan orang dewasa. 
Hasil penelitian di Indonesia pemberian ASI biasanya rata-rata balita diberikan ASI sampai usia 2 tahun. ASI sebagai makanan utama cukup baik bagi pertumbuhan bayi sampai usia 6 bulan. Setelah berusia 6 bulan diberikan makanan pendamping ASI dengan tetap memberikan ASI sampai usia 24 bulan (Nelson, 2006: 21). Menurut Jellife (2007) Air Susu Ibu hendaknya diberikan terus sampai anak berusia 2 tahun sebab ASI mengandung zat-zat gizi yang penting bagi anak, yang tidak terdapat dalam susu sapi. Proses lama pemberian ASI sebaiknya dihentikan pada waktu anak berumur 2 tahun, karena zatzat yang terkandung di dalam ASI sudah tidak dapat mencukupi kebutuhan anak.

Menghentikan lama pemberian ASI diusia kurang dari 2 tahun salah satunya dipengaruhi oleh aktivitas ibu diluar rumah untuk bekerja sehingga mengharuskan melakukan penghentian pemberian ASI yang digantikan oleh pemberian susu formula. Status gizi anak yang baik juga dipengaruhi oleh makanan pendamping ASI (MP/ASI) yang cukup dan pemberian ASI yang optimal sampai anak usia 2 tahun.

Pemberian susu formula pada anak, dianggapnya praktis akan tetapi tidak diberikan ASI biasanya dapat menimbulkan anak obesitas atau gerak anak menjadi kurang aktif (www.unnes.ac.id, 4 Agustus 2010).

\section{SIMPULAN}

Berdasarkan hasil penelitian didapatkan kesimpulan:

1. Lama pemberian ASI mayoritas $\geq$ 2 th sebanyak $72,5 \%$

2. Status gizi balita usia 24-59 bulan mayoritas berstatus gizi normal berdasar PB/U sebanyak $62,5 \%$

3. Ada hubungan antara lama pemberian ASI dengan status gizi balita $p$ value 0,014 .

\section{DAFTAR PUSTAKA}

Arafiani, M. 2007. Hubungan Antara Lama Pemberian ASI Dan Frekuensi Kehadiran Balita Di Posyandu Dengan Status Gizi Balita Usia 12-24 Bulan. Skripsi.Program Studi Ilmu Gizi Fakultas Kedokteran. Universitas Diponegoro, Semarang. www.bkkbn.go.id, 23 Januari 2018

Lucy, 2006, Strategi Nasional PP ASI, diakses 20 Februari 2010, Depkes RI 2006, Dirjen Biskesmas Direktorat Gizi Masyarakat, Manajemen Laktasi Buku Panduan bagi Bidan dan Petugas Kesehatan di Puskesmas, Jakarta.www.digilib.unnes.ac.i d, 20 Februari 2018

Perinesia, BKK PPASI, 2004, Bahan Bacaan Manajemen Laktasi, Cetakan kedua, Perinesia BKK PPASI, Jakarta 